\title{
Dietary Effect on the Proteome of the Common Octopus (Octopus vulgaris) Paralarvae
}

\author{
Inmaculada Varó ${ }^{1 *}$, Gabriel Cardenete ${ }^{2}$, Francisco Hontoria ${ }^{1}$, Óscar Monroig ${ }^{1,3}$, \\ José Iglesias ${ }^{4}$, Juan J. Otero ${ }^{4}$, Eduardo Almansa ${ }^{5}$ and Juan C. Navarro ${ }^{1}$ \\ ${ }^{1}$ Instituto de Acuicultura Torre de la Sal (CSIC), Ribera de Cabanes, Castellón, Spain, ${ }^{2}$ Departamento de Zoología, \\ Universidad de Granada, Granada, Spain, ${ }^{3}$ Faculty of Natural Sciences, Institute of Aquaculture, University of Stirling, Stirling, \\ Scotland, ${ }^{4}$ Centro Oceanográfico de Vigo, Instituto Español de Oceanografía, Vigo, Spain, ${ }^{5}$ Centro Oceanográfico de \\ Canarias, Instituto Español de Oceanografía, Santa Cruz de Tenerife, Spain
}

\section{OPEN ACCESS}

Edited by:

Fernando Ariel Genta, Oswaldo Cruz Foundation, Brazil

Reviewed by:

Germán Leandro Rosano, Instituto de Biología Molecular y Celular de Rosario, Argentina Jesper Givskov Sørensen,

Aarhus University, Denmark

*Correspondence: Inmaculada Varó inma@iats.csic.es

Specialty section

This article was submitted to Invertebrate Physiology, a section of the journa Frontiers in Physiology

Received: 15 February 2017 Accepted: 28 April 2017 Published: 17 May 2017

Citation:

Varó I, Cardenete G, Hontoria F Monroig Ó, Iglesias J, Otero JJ, Almansa E and Navarro JC (2017) Dietary Effect on the Proteome of the Common Octopus (Octopus vulgaris) Paralarvae. Front. Physiol. 8:309. doi: 10.3389/fphys.2017.00309
Nowadays, the common octopus (Octopus vulgaris) culture is hampered by massive mortalities occurring during early life-cycle stages (paralarvae). Despite the causes of the high paralarvae mortality are not yet well-defined and understood, the nutritional stress caused by inadequate diets is pointed out as one of the main factors. In this study, the effects of diet on paralarvae is analyzed through a proteomic approach, to search for novel biomarkers of nutritional stress. A total of 43 proteins showing differential expression in the different conditions studied have been identified. The analysis highlights proteins related with the carbohydrate metabolism: glyceraldehyde-3-phosphate-dedydrogenase (GAPDH), triosephosphate isomerase; other ways of energetic metabolism: $\mathrm{NADP}^{+}$-specific isocitrate dehydrogenase, arginine kinase; detoxification: glutathione-S-transferase (GST); stress: heat shock proteins (HSP70); structural constituent of eye lens: S-crystallin 3; and cytoskeleton: actin, actin-beta/gamma1, beta actin. These results allow defining characteristic proteomes of paralarvae depending on the diet; as well as the use of several of these proteins as novel biomarkers to evaluate their welfare linked to nutritional stress. Notably, the changes of proteins like S-crystallin 3, arginine kinase and $\mathrm{NAD}^{+}$specific isocitrate dehydrogenase, may be related to fed vs. starving paralarvae, particularly in the first 4 days of development.

Keywords: Octopus vulgaris, paralarvae, nutritional stress, proteome, novel biomarkers, welfare

\section{INTRODUCTION}

The common octopus (Octopus vulgaris) is one of the most important cephalopod species recommended for European aquaculture diversification due mainly to its rapid growth, elevated food conversion index, and high market demand and price (Navarro and Villanueva, 2000; VazPires et al., 2004; Iglesias et al., 2007). Nowadays its culture is hampered by massive mortalities (Iglesias and Fuentes, 2014) occurring during early life-cycle stages, (paralarvae), representing the main obstacle for commercial production of this species (Iglesias et al., 2007, 2014; Villanueva and Norman, 2008). In fact, the life cycle of O. vulgaris under captivity conditions was completed for the first time in 2001 (Iglesias et al., 2004), but until now, it has not been possible to successfully rear the paralarvae up to juveniles and sub-adults with acceptable survivals for the commercial production 
of this species (Rodríguez and Carrasco, 1999; Móxica et al., 2002; Iglesias et al., 2014). The actual causes of such mortality remain unknown, although failure to fulfill the dietary requirements for key nutrients particularly essential lipids appear to be a major factor (Navarro et al., 2014). Thus, substantial efforts have been made to associate dietary lipids to mortality and growth at paralarval stages (Navarro and Villanueva, 2000, 2003; Seixas et al., 2010; Monroig et al., 2012a,b; Navarro et al., 2014), with meta-analysis techniques pointing out clearly at this link (Garrido et al., 2016a). However, the lack of substantial differences in performance between the experimental dietary regimes and control treatments in paralarval cultures fed diets with different essential lipid profiles suggested that other not yet explored factors account for the high mortality mentioned above. Thus, the zootechnical productions may undergo some unspecific stress that adds up to the putative nutritional deficiencies contributing very significantly to reduced paralarval welfare manifested in very low survival and depressed growth.

Like for most early stages of marine fish and crustaceans, feeding is based in the use of live preys. Artemia nauplii and metanauplii are extensively used as food for availability reasons, but crustacean zoeae (Maja, Pagurus, Grapsus) seem a more suitable and natural prey from the view point of their nutritional composition, and have been used with some success (Iglesias et al., 2004, 2014; Navarro et al., 2014; Garrido et al., 2016a). Recently, the culture in big volumes (1,000 L tanks) with the use of ongrown Artemia biomass using microalgae, like Nannochloropsis or Isochriysis, as food (Iglesias et al., 2004, 2006; Fuentes et al., 2011) have moderately improved paralarval survival, but still far from industrial scenarios. To the nutritional stress caused by inadequate and/or unbalanced diets (Iglesias et al., 2007; Garrido et al., 2016b), and lack of optimal reproducible culture protocols, it should be added that there is little knowledge on paralarvae physiology and behavior allowing to understand the poor culture performance. In fact, studies on the basic processes involved in nutritional and physiological stress are limited in cephalopod paralarvae. Under such an unmanageable panorama, omics technologies, specifically proteomic approaches come at hand.

Proteins form a major class of macronutrients, because they participate in every cellular process. Therefore, the global profiling of the proteome, defined as the entire protein complement of the genome expressed at a particular time, offers the potential for identification of important biomarkers of nutritional state that respond to alterations in diet. Currently, nutritional research is taking advantage of proteomics technologies to discover biologically active food components, to assess their quality and safety, and to demonstrate their biological efficacy. For example, using proteomics, it was shown that in mice, the consumption of different dietary oils induced either differential expression of long chain acyl-CoA thioester hydrolase protein as an indicator of $\beta$-oxidation of fatty acids in the liver, or differential expression of adipophilin protein as an indicator of selective hepatic lipid accumulation and triglyceride secretion (Roos and McArdle, 2008). Proteomics was also applied to explain the mechanisms underlying changes in hepatic lipid metabolism of rats during zinc deficiency
(Tom Dieck et al., 2005 cited by Roos and McArdle, 2008). Regarding fish species, zebrafish proteome was altered by calorie restriction (Jury et al., 2008) and rainbow trout proteome was found to reflect dietary manipulations (Martin et al., 2003). Thus, application of proteomics techniques to "map" and read metabolic dysfunctionalities of octopus paralarvae seem a more than promising field.

Up to date, all previous studies of nutritionally-derived stress in paralarvae cultures of the common octopus have been carried out using conventional approaches, testing the effects of a variable on potential (bio)markers of such effects (Garrido et al., 2017). Global protein profiling offers the potential of comparing control vs. treated animals (or the effects of different dietary treatments) beyond the frame of an aprioristic approach, in the search of highlighted differences that can help to establish clues about the metabolic pathways affected. We report here on an experiment analyzing the proteomes of $O$. vulgaris paralarvae, comparing the effect of fasting during the early days of development, as well as the response of two dietary treatments based on either enriched Artemia metanauplii or crustacean zoeae as live preys.

\section{MATERIALS AND METHODS}

\section{Paralarval Rearing}

$O$. vulgaris paralarvae were obtained from a broodstock kept at the Spanish Institute of Oceanography IEO (Vigo), following the rearing conditions described by Móxica et al. (2002). Paralarvae were raised up in black cylindrical $500 \mathrm{~L}$ tanks until 16 days, before massive mortalities start. The initial paralarvae density was 10 individuals $\mathrm{L}^{-1}$ (5,000 individuals per tank). A closed water circuit was used during the first 5 days and partly opened $(4 \mathrm{~h} /$ day) until the end of the experiment. The temperature was kept at $21-23^{\circ} \mathrm{C}$, and the salinity at $35 \mathrm{psu}$. Central aeration and drainage were used for water renovations and surface cleaners based on air pressure were applied. The light intensity in the tank surface was of 800-1,000 lux during $24 \mathrm{~h}$.

Two dietary treatments were tested. Artemia group (A) consisted of paralarvae fed Artemia nauplii (Sep-Art EG, INVE Aquaculture, Belgium) enriched with the microalgae Nannochloropsis sp. and Isochrysis galbana at 0.5 individuals $\mathrm{mL}^{-1}$ per day. Zoeae group $(Z)$ consisted of paralarvae fed live crustacean zoeae (Maja brachydactyla) at 0.01 Maja zoeae $\mathrm{mL}^{-1}$ per day in co-feeding with (A). Co-feeding was unavoidable from the evidence that the production of Maja zoeae did not suffice to keep a prey density equivalent to treatment $\mathrm{A}$. Thus, every effort was made to try to keep similar prey densities in both treatments. Also, an unfed paralarvae group, named (I), was kept from hatchling to day 4. M. brachydactyla zoeae were produced as described in Iglesias et al. (2014).

Paralarvae dry weight was determined individually after oven drying for $20 \mathrm{~h}$ at $110^{\circ} \mathrm{C}$ as described in Iglesias et al. (2014). Before, animals were sacrificed in chilled seawater $\left(-2^{\circ} \mathrm{C}\right)$ and rinsed in distilled water.

Pooled paralarval (5-10) samples were collected from each experimental group at days 0,4 , and 16 for proteomic analysis. The samples were rinsed, frozen in liquid nitrogen and stored 
at $-80^{\circ} \mathrm{C}$ until analyzed. The study was exempt from ethics approval, since the zootechnical experiments were performed in 2013 before the Spanish Legislation made it compulsory by established Ethical Committees in the Research Institutions. The experiments were conducted under ethical protocols and recommendations that are nowadays fully compliant with the European directive (2010/63/EU), the Spanish law (RD 53/2013), and the Guidelines for the Care and Welfare of Cephalopods in Research (Fiorito et al., 2015).

\section{D Differential in Gel Electrophoresis (2D-DIGE): Sample Preparation and Protein Labeling}

Proteins from samples were directly extracted in DIGE lysis buffer (7 M urea, $2 \mathrm{M}$ thiourea, 4\% CHAPS, $30 \mathrm{mM}$ Tris and $1 \mathrm{x}$ complete protease inhibitor EDTA free, Roche) using the $2 \mathrm{D}$ grinding kit system (General Electric Healthcare). The solubilized proteins were separated from non-solubilized cellular components by centrifugation $(20,000 \mathrm{~g} \times 20 \mathrm{~min})$. Salts and any interfering components were removed using the 2D Cleanup kit (GE Healthcare) and after precipitation, proteins were resolublized in DIGE label buffer (7 M urea, $2 \mathrm{M}$ thiourea, 4\% CHAPS, $20 \mathrm{mM}$ Tris-pH 8.5). Protein concentration was determined using the Bradford Bio-Rad Protein Assay (RcDc Kit) with bovine serum albumin (BSA) as standard.

Proteins from each experimental group were randomly labeled either with $\mathrm{Cy} 3$ or $\mathrm{Cy} 5$ following to the manufacturer's instructions (GE Healthcare). Briefly, $50 \mu \mathrm{g}$ protein of each sample was labeled with 400 pmol CyDye DIGE Fluor minimal Dye by vortexing and incubated on ice in the dark for $60 \mathrm{~min}$. The labeling reaction was stopped with $1 \mu \mathrm{L}$ of $10 \mathrm{mM}$ lysine followed by incubation on ice for $10 \mathrm{~min}$. An internal standard sample was prepared by pooling $25 \mu \mathrm{g}$ of protein from each sample, and by labeling by Cy 2 as described above. Differentially labeled samples $(150 \mu \mathrm{g}$ total protein) were mixed and $65 \mathrm{mM}$ DTT and $1 \%$ ampholytes ( $\mathrm{pH}=3-10 \mathrm{NL}$ ) were added to the mixture before running the first dimension.

\section{Gel Electrophoresis (2D-Dige Gel): Separation and Image Capture}

A total of 24 protein samples (6 experimental groups $\times 4$ biological replicates, Supplementary Table 1) were combined in pairs, and analyzed on a total of 12 2D gels following the experimental design given in Supplementary Table 2. $24 \mathrm{~cm}$ - IPG strips $(\mathrm{pH}=3-11 \mathrm{NL}$ ) were rehydrated in $8 \mathrm{M}$ urea, 4\% CHAPS, DeStreak $\left(12 \mu \mathrm{L} \mathrm{mL} \mathrm{m}^{-1}\right)$, and $1 \%$ ampholytes $(\mathrm{pH}=3-10$ $\mathrm{NL}$ ) overnight at room temperature. Cy-labeled samples were applied onto IPG rehydrated strips via anodic cup loading, and IEF (first dimension) was performed on a Ettan IPGphor II horizontal electrophoresis system (GE Healthcare) at $20^{\circ} \mathrm{C}$ using the following IEF protocol: step 1:300 V $4 \mathrm{~h}$, gradient to 1,000 $\mathrm{V} 6 \mathrm{~h}$, gradient to $8,000 \mathrm{~V} 3 \mathrm{~h}$; step 2: $8,000 \mathrm{~V}$ until reached $32,000 \mathrm{Vh}$.

After IEF, the strips were reduced in equilibration buffer [Tris $50 \mathrm{mM}$, urea $6 \mathrm{M}$, and glycerol $30 \%(\mathrm{v} / \mathrm{v}), 2 \%$ SDS (w/v)] containing $2 \% \mathrm{DTT}(\mathrm{w} / \mathrm{v})$, for $15 \mathrm{~min}$ at room temperature; followed by alkylation in equilibration buffer containing $2.5 \%$ $(\mathrm{w} / \mathrm{v})$ iodoacetamide, for $15 \mathrm{~min}$ at room temperature. The proteins were then separated (second dimension) on $12.5 \%$ acrylamide SDS-PAGE gels $(25 \mathrm{~cm} \times 21 \mathrm{~cm} \times 1 \mathrm{~mm})$ using an Ettan DaltSix Unit (GE Healthcare) electrophoresis system at $2 \mathrm{~W}$ per gel for $1 \mathrm{~h}$ and $15 \mathrm{~W}$ per gel for $6 \mathrm{~h}$.

After electrophoresis, the 2-D gels were scanned with a Typhoon $^{\text {TM }} 9400$ Variable Mode Imager, at $100 \mu \mathrm{m}$ resolution to visualize the labeled proteins. Excitation/emission wavelengths were chosen specifically for $\mathrm{Cy} 2, \mathrm{Cy} 3$, and Cy5 according to manufacturer's recommendations (GE Healthcare).

\section{Data Analysis}

Fluorescence images were analyzed using DeCyder ${ }^{\mathrm{TM}} 2 \mathrm{D}$ software (v.7.0) and the multivariate statistical module EDA (Extended Data Analyses; GE, Healthcare), as described in Varó et al. (2010). First, the intra-gel images were individually processed by DeCyder-DIA (Differential In-gel Analyses) software module to co-detect and differentially quantify the protein spots in the images, taking the internal standard as reference to normalize the data, and with the threshold set to 2 standard deviations. Thereafter, the DeCyder-BVA (Biological Variation Analysis) was applied to inter-gel matching, and differences in average ratios of protein expression were analyzed by the Student's $t$ - test and One-Way ANOVA, with $p \leq 0.05$ being considered significant. Finally, EDA software was used for multivariate statistical analysis of data. Principal components analyses (PCA) were carried out using an algorithm included in the EDA software, incorporating only data from proteins present in at least $90 \%$ of the spot maps and applying a $t$-test filter $(p \leq 0.05)$.

\section{Mass Spectrometry}

Protein spots showing significantly altered expression levels between groups were manually excised from analytical silver stained gels and digested with sequencing grade trypsin (Promega) as described elsewhere (Shevchenko et al., 1996). The digestion was stopped with $0.1 \%$ TFA (trifluoroacetic acid, Sigma) and the digested peptides were concentrated to $7 \mu \mathrm{L}$. BSA plug was analyzed in the same way to control the digestion process.

Digested samples were subjected to PMF-MS/MS (MALDITOF-TOF) and/or LC-MS/MS analyses.

\section{PMF-MS/MS (MALDI-TOF-TOF) Analysis}

Previously, MALDI plate and the acquisition methods were calibrated with $0.5 \mu \mathrm{L}$ of the CM5 calibration mixture (ABSciex) in 13 positions. The resulting mixtures were analyzed in a 5800 MALDI- TOF-TOF (ABSciex) in positive reflection mode $(3,000$ shots in every position). Five of the most intense precursors (according to the threshold criteria: minimum signal-to-noise: 10, minimum cluster area: 500, maximum precursor gap: 200 ppm, maximum fraction gap: 4) were selected for every position for the MS/MS analysis, and data was acquired using the default $1 \mathrm{kV}$ MS/MS method. The MS and MS/MS information was sent to MASCOT via the Protein Pilot (v 4.5 ABSciex) to be identified. 


\section{LC-MS/MS Analysis}

Protein spots without a positive identification were analyzed by LC-MS/MS. $5 \mu \mathrm{L}$ of each sample were loaded onto a trap column (NanoLC Colum, $3 \mu \mathrm{C} 18-\mathrm{CL}, 350 \mu \mathrm{m} \times 0.5 \mathrm{~mm}$; Eksigen) and desalted with $0.1 \% \mathrm{TFA}$ at $3 \mu \mathrm{L} / \mathrm{min}$ for $5 \mathrm{~min}$. Then, peptides were loaded onto an analytical column (LC Column, $3 \mu \mathrm{m} \mathrm{C18-}$ $\mathrm{CL}, 75 \mu \mathrm{m} \times 12 \mathrm{~cm}$, Nikkyo) and equilibrated in $5 \%$ acetonitrile $(\mathrm{ACN}), 0.1 \%$ formic acid (FA). The peptide elution was carried out with a linear gradient of $5-45 \%$ B in A for 15 min (A: $0.1 \%$ FA; B: ACN, $0.1 \%$ FA) at a flow rate of $300 \mathrm{~nL} / \mathrm{min}$. Peptides were analyzed in a nanoESI qQTOF mass spectrometer 5600 Triple TOF (ABSciex). The tripleTOF was operated in informationdependent acquisition mode, followed by 0.05 -s product ion scan from 100 to $1,500 \mathrm{~m} / \mathrm{z}$ on the 50 most intensive $2-5$ charged ions. LC-MS/MS information was analyzed using Protein Pilot search engine software (v.4.5; ABSciex).

\section{Protein Identification}

The PMF search was performed on NCBI databases. Searches were done with tryptic specificity allowing one missed cleavage and a tolerance on the mass measurement of $100 \mathrm{ppm}$ in MS mode and 0.8 Da for MS/MS mode. Carbamidomethylation of Cys was used as a fixed modification and oxidation of Met and deamidation of Asn and Gln as variable modifications.

For LC-MS/MS data Protein Pilot search engine software (v.4.5 ABSciex) was used. Protein Pilot default parameters were used to generate a peak list directly from 5600 TripleTof wiff files. The Paragon algorithm of Protein Pilot was used to search NCBI protein database with the following parameters: trypsin specificity, iodoacetamidecys-alkylation, no taxonomy restriction, and the search effort set to rapid.

For ESTs identifications, the MGF (mascot generic file) generated by Protein Pilot were sent to MASCOT via the Deamon software (Matrix Science). Database search was performed on ESTs database: EST_cephalopoda cephalopoda_140224 (684204 sequences; 143385132 residues). Searches were done with tryptic specificity allowing one missed cleavage and a tolerance on the mass measurement of $50 \mathrm{ppm}$ in MS mode and $0.6 \mathrm{Da}$ in MSMS mode. Carbamidomethylation of Cys was used as a fixed modification and oxidation of Met and deamidation of Asn and Gln as variable modifications.

\section{RESULTS}

\section{Dry Weight}

The dry weight of paralarvae at hatching was $0.333 \pm$ $0.080 \mathrm{mg}$. At 4 days unfed paralarvae decreased their weight to $0.177 \pm 0.070 \mathrm{mg}$, whereas values of $0.411 \pm 0.014 \mathrm{mg}$ and $0.367 \pm 0.033 \mathrm{mg}$ were reached by $\mathrm{Z}$ and A groups. At 16 days, these raised again to $0.713 \pm 0.062 \mathrm{mg}$ and $0.621 \pm 0.051 \mathrm{mg}$ respectively.

\section{DIGE Analyses and Protein Identification}

The 12 gel images were subsequently analyzed using the DeCyder-DIA and BVA modules comparing the proteome of the 4 different conditions considered important as function of dietary group and age (Supplementary Table 3). Representative
2D-DIGE gels (gel master) of octopus paralarvae proteins from condition 1, comparing unfed 4 days old paralarvae (I4) with hatchlings (I0), is shown in Figure 1. A total of 4,507 proteins were detected in the gel master over the range of $\mathrm{pH} 3-11 \mathrm{NL}$ and a molecular weight from approximately $10-250 \mathrm{kDa}$ used in this study. BVA analyses revealed in condition 1 (I4 vs. I0), a total of 23 spots of proteins that showed significant changes in expression related with age ( $t$-test, $p \leq 0.05)$. Among these protein spots, 11 were up regulated and 12 down regulated in the older unfed paralarvae (I4). From this set of proteins, it was possible to identify 16 proteins using mass spectrometry (Supplementary Tables 4-6). When fed and unfed 4 days old paralarvae (condition 2: A4, Z4 vs. I4) were compared, 24 proteins (22 up regulated and 2 down regulated) presented differential expression in fed paralarvae (one-way ANOVA, $p \leq 0.05$ ). Of these, 15 protein spots were identified by mass spectrometry. In condition 3 (Z4 vs. A4) and 4 (Z16 vs. A16), where 4 and 16 days old paralarvae of both dietary groups were compared, a total of 10 ( 8 up regulated and 2 down regulated) and 7 protein spots (3 up regulated and 4 down regulated) respectively showed significant differences in expression $(t$-test, $p \leq 0.05)$ between zoeae and Artemia dietary groups. A total of 6 protein spots were identified in each condition by mass spectrometry. The $2 \mathrm{D}$ DIGE analyses (spot no., $p$-value, fold change) and the results of protein identities differentially expressed in each condition are given in Table 1. Principal component analyses (PCA) and hierarchical cluster analyses of data for each condition are shown in Figures 2-5. The PCA results revealed a good separation of paralarvae groups from a specific sub-set of significant protein spots as function of diet and age in each condition. The dendogram after hierarchical cluster analyses also show a good separation of the spot maps as function of diet and age in each condition.

A total of 55 spots that showed significant differences in the experimental groups after gel image analyses, and with enough quantity of protein to be manually excided from analytical gels, were selected for protein identification by MS. From these, 43 protein spots were successfully identified in public databases. Different protein spots were identified as the same protein due post-translational modifications. Some of the identified proteins were found to be involved in several metabolic pathways, related with carbohydrate metabolism [glyceraldehyde-3-phosphate-dedydrogenase (GAPDH), triosephosphate isomerase], and other pathways of energetic metabolism (NADP+-specific isocitrate dehydrogenase and arginine kinase). Other identified proteins were related with detoxification [glutathione-S-transferase (GST)], stress [heat shock proteins (HSP70)], structural constituent of eye lens (S-crystallin 3), and cytoskeleton (actin, actin-beta/gamma1, and beta actin). Table 2 summarizes the main changes in expression of the above-mentioned proteins in the different conditions studied as function of dietary group and age. It is interesting to note the up-regulation of GAPDH, a key protein in carbohydrate metabolism, in all conditions, with the 16 days old zoeae fed group (Z16, condition 4) showed the highest fold change (3.21-fold). In condition 1, unfed paralarvae (I4) presented 2 proteins involved in carbohydrate metabolism, 


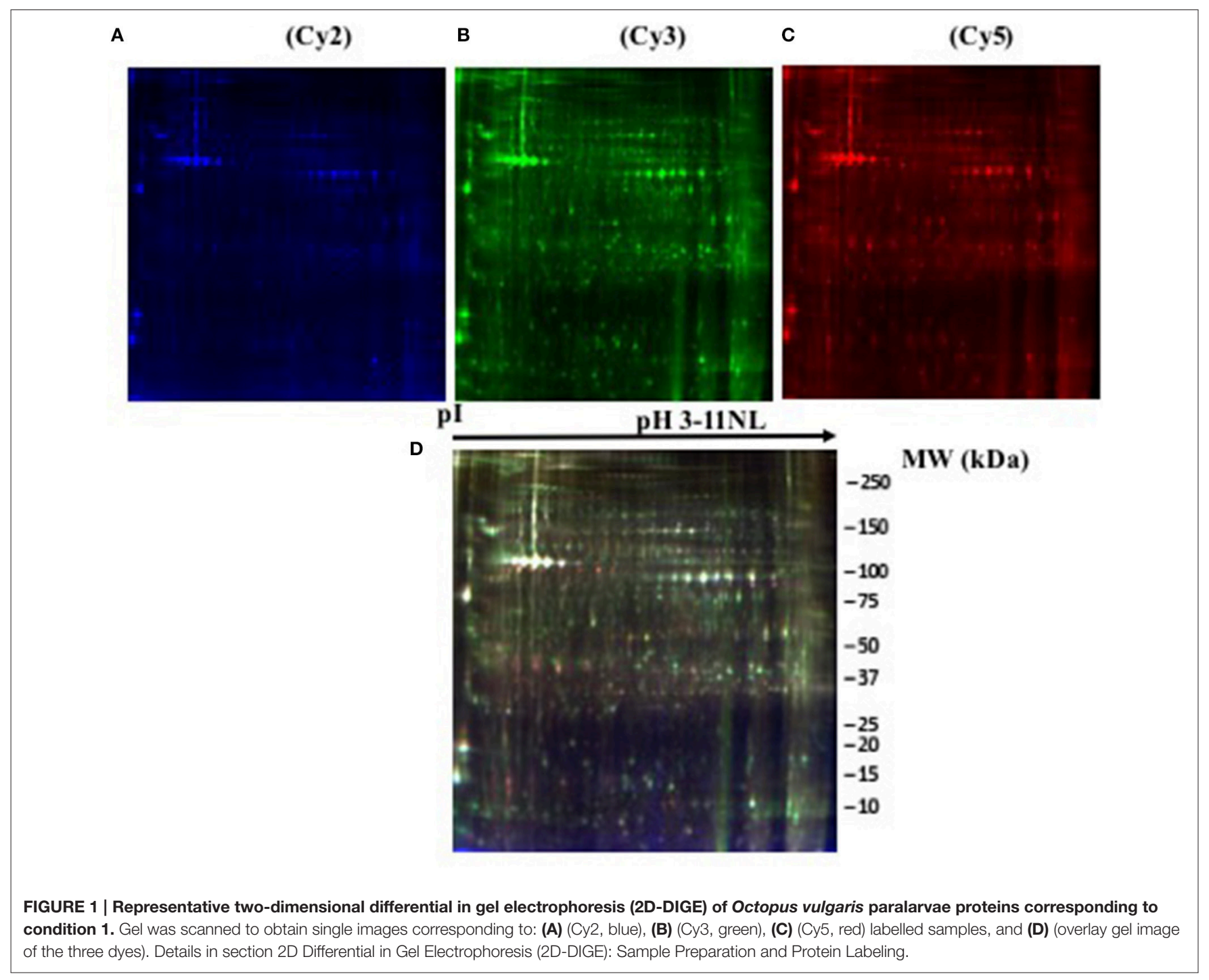

one of which was up regulated (GAPDH), whereas another (triosephosphate isomerase) was down regulated. Other 2 up regulated proteins were associated with vision function (S-crystallin 3, by over $\sim 2$-fold) and cytoskeletal structure (beta actin, increased 1.35-fold). Finally, another 2 down regulated (by over $\sim 2$-fold) proteins were related with stress (HSP70) and detoxification (GST). Four days old fed paralarvae (A4 and Z4, condition 2) showed an increase in abundance in all the proteins identified, except for the spot 1,090 (hypothetical protein LOTGIDRAFT_231565), which decreased by $\sim 1$-fold. Also, it is to note that in fed paralarvae groups there was overexpression of proteins involved in energy metabolism (arginine kinase, 19.5-fold) and NADP+-specific isocitrate dehydrogenase, 7.72-fold) and vision (S-crystallin 3, 8.44-fold) compared with unfed paralarvae group (I4). Moreover, an increase in a protein involved in nitrogen metabolism (nitrilase, 4.25-fold), and in two isoforms of actin (actin, 3.76-fold and actin beta/gamma I, 2.25-fold) was identified in fed paralarvae groups. When both dietary groups were compared (condition 3 and 4), the common proteins identified with differential expression, showed also similar changes in abundance. Interestingly, most of the proteins showing significant changes were up regulated in 4 days old paralarvae, while the opposite occurs in 16 days old paralarvae. It is to note that in Z4 group (condition 3), two of the three proteins involved in energy metabolism (GAPHD and arginine kinase) increased, whereas the third (NADP+-specific isocitrate dehydrogenase) decreased. S-crystallin3 decreased only (2.27-fold) in Z16 group (condition 4).

\section{DISCUSSION}

Common practice in $O$. vulgaris paralarval rearing is to use spawns from single females. This is practically unavoidable because $O$. vulgaris is a semelparous species, and under the current state of the art, broodstock has to be captured from the wild, each with a different feeding and maturation background. Once captured, each female spawns at different times, and the 
TABLE 1 | Protein identities differentially expressed in Octopus vulgaris paralarvae in the different conditions studied as function of dietary group and age.

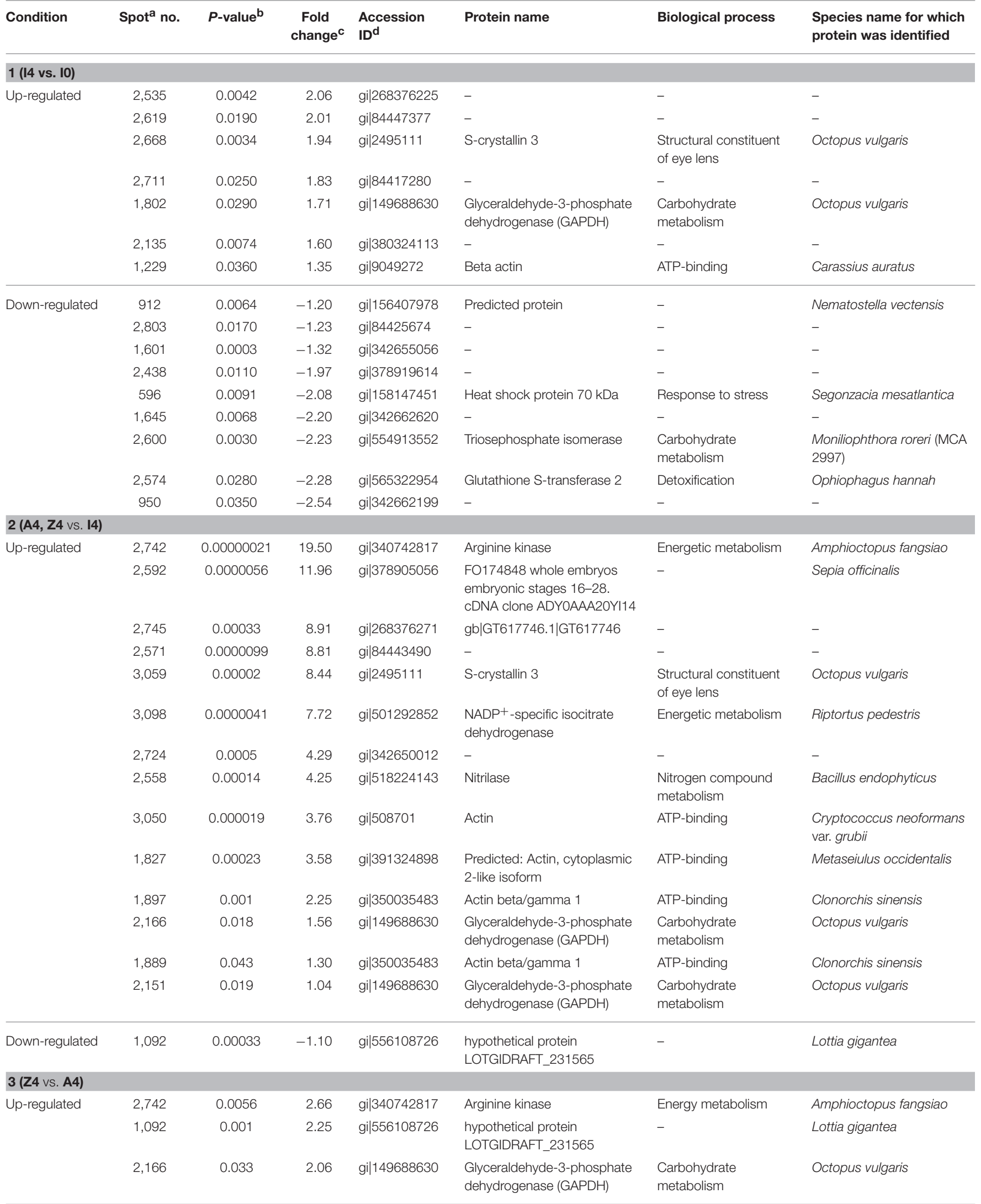


TABLE 1 | Continued

\begin{tabular}{|c|c|c|c|c|c|c|c|}
\hline Condition & Spot $^{a}$ no. & $P$-value ${ }^{b}$ & $\begin{array}{l}\text { Fold } \\
\text { change }^{c}\end{array}$ & $\begin{array}{l}\text { Accession } \\
\text { ID }^{d}\end{array}$ & Protein name & Biological process & $\begin{array}{l}\text { Species name for which } \\
\text { protein was identified }\end{array}$ \\
\hline & 2,151 & 0.0066 & 2.05 & gi|149688630 & $\begin{array}{l}\text { Glyceraldehyde-3-phosphate } \\
\text { dehydrogenase (GAPDH) }\end{array}$ & $\begin{array}{l}\text { Carbohydrate } \\
\text { metabolism }\end{array}$ & Octopus vulgaris \\
\hline & 1,889 & 0.023 & 1.52 & gi|350035483 & Actin beta/gamma 1 & ATP-binding & Clonorchis sinensis \\
\hline Down-regulated & 2,558 & 0.01 & -1.73 & gi|518224143 & Nitrilase & $\begin{array}{l}\text { Nitrogen compound } \\
\text { metabolism }\end{array}$ & Bacillus endophyticus \\
\hline \multicolumn{8}{|l|}{4 (Z16 vs. A16) } \\
\hline Up-regulated & 2,151 & 0.013 & 3.21 & gi|149688630 & $\begin{array}{l}\text { Glyceraldehyde-3-phosphate } \\
\text { dehydrogenase (GAPDH) }\end{array}$ & $\begin{array}{l}\text { Carbohydrate } \\
\text { metabolism }\end{array}$ & Octopus vulgaris \\
\hline \multirow[t]{5}{*}{ Down-regulated } & 2,724 & 0.041 & -1.15 & gi|342650012 & - & - & - \\
\hline & 3,059 & 0.011 & -2.27 & gi|2495111 & S-crystallin 3 & $\begin{array}{l}\text { Structural constituent } \\
\text { of eye lens }\end{array}$ & Octopus vulgaris \\
\hline & 1,827 & 0.037 & -2.41 & gi|391324898 & $\begin{array}{l}\text { Predicted: Actin, cytoplasmic } \\
\text { 2-like isoform }\end{array}$ & ATP-binding & Metaseiulus occidentalis \\
\hline & 2,558 & 0.021 & -2.65 & gi|518224143 & Nitrilase & $\begin{array}{l}\text { Nitrogen compound } \\
\text { metabolism }\end{array}$ & Bacillus endophyticus \\
\hline & 3,098 & 0.017 & -2.85 & gi|501292852 & $\begin{array}{l}\text { NADP-specific isocitrate } \\
\text { dehydrogenase }\end{array}$ & Energetic metabolism & Riptortus pedestris \\
\hline
\end{tabular}

\footnotetext{
a spot numbering.

${ }^{b}$ Student $t$-test $P$-value.

${ }^{C}$ Average fold change ratio in each condition as calculated by DeCyder BVA analysis.

${ }^{d}$ Protein accession number from NCBI.

- Denotes non-identified.
}

egg masses undergo a long embryonic phase, making almost impossible to synchronize different hatchings. One point to consider then, is whether the molecular behavior of the offspring is linked to the genetic background of the female in particular. It has to be noted, however, that intercalibration approaches carried out among different laboratories (Garrido et al., 2017) and meta-analysis studies (Garrido et al., 2016a) reveal that above of the unavoidable variability inherent to the geographical origin and rearing scenarios, most rearing problems and physiological responses of the paralarvae are repetitive.

As far as we know, this is the first study using a proteomic approach to analyze the effect of diet and to search novel biomarkers of nutritional stress on octopus paralarvae. The proteome of octopus paralarvae according to the multivariate analyses (PCA and hierarchical), showed that changes in specific sub-sets of proteins differentially expressed as function of diet and age, allowed to describe characteristic proteomes for each experimental condition (see Figures 2-5). Similar result has been previously reported by Sveinsdóttir and Gudmundsdóttir (2010) for Atlantic cod (Gadus morhua) larvae using proteome analysis to study feeding effects. These authors found changes in abundance in a sub-set of 13 protein spots in the proteome of cod larvae fed with saithe (Pollachius virens) protein hydrolysate (SPH). Among the proteins identified here, it is noteworthy that most are involved in energy metabolism such as glyceraldehyde-3phosphate dehydrogenase (GAPDH), triosephosphate isomerase, $\mathrm{NADP}+$-specific isocitrate dehydrogenase, and arginine kinase. This is not surprising since, early development of many marine organisms undergoing larval phases, and particularly of octopus paralarvae is highly dependent on energy for growth (von Boletzky and Villanueva, 2014). Other proteins identified are involved in several cellular processes related with detoxification (GST), stress [heat shock proteins (HSP70)], vision (S-crystallin 3) and cytoskeleton (actin, actin-beta/gammal and beta actin), physiologically crucial during early life stages of development.

The enzyme GAPDH has been known mainly as a "housekeeping" protein (Barber et al., 2005), with a role as key intermediate component of glycolysis and as a source of $\mathrm{NADH}$. In fact, GADPH transforms glyceraldehyde-3-phosphate to glycerate 1,3-bisphospate and mediates the formation of $\mathrm{NADH}$ and ATP. The up-regulation of GAPDH in all conditions analyzed in our work could be related with these functions. Paralarval stages show a very active metabolism and fast growth, so obtaining energy and reducing power are essential. Besides, GADPH has demonstrated to be a multifunctional protein at least in vertebrates (Sirover, 1999; Baumgarner et al., 2012), displaying diverse activities including membrane, cytoplasmic and nuclear functions in endocytosis, mRNA regulation, DNA replication and repair, as well as regulation of apoptosis, as has been demonstrated in mammals (Sirover, 1997, 2011; Tristan et al., 2011). GAPDH expression has also been associated with exposure to hypoxia or anoxia and temperature variation in fish (Smith et al., 2009; Baumgarner et al., 2013; Jayasundara et al., 2015), and in mammals with a function of the cell proliferative state (MeyerSiegler et al., 1992; Mansur et al., 1993; Gong et al., 1996). This last fact could also be the common origin of the over expression of GAPDH found in paralarvae of all conditions, considering the 
A

$$
\text { Spot Maps (Score Plot) }
$$

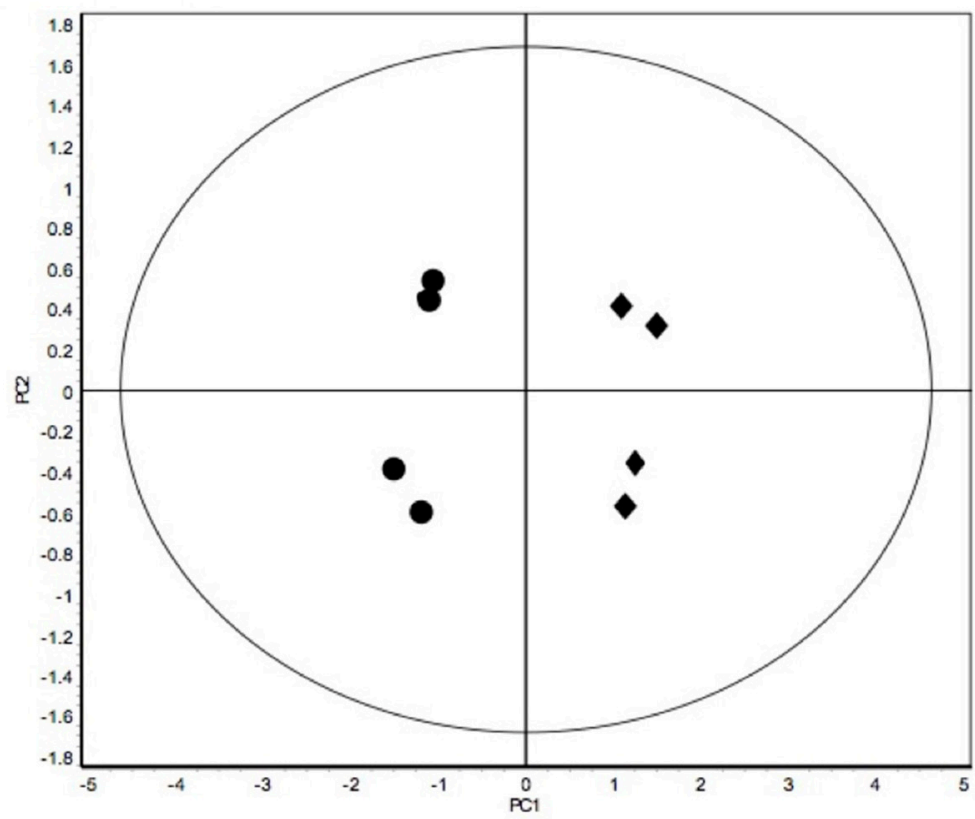

I-0

I-4

B

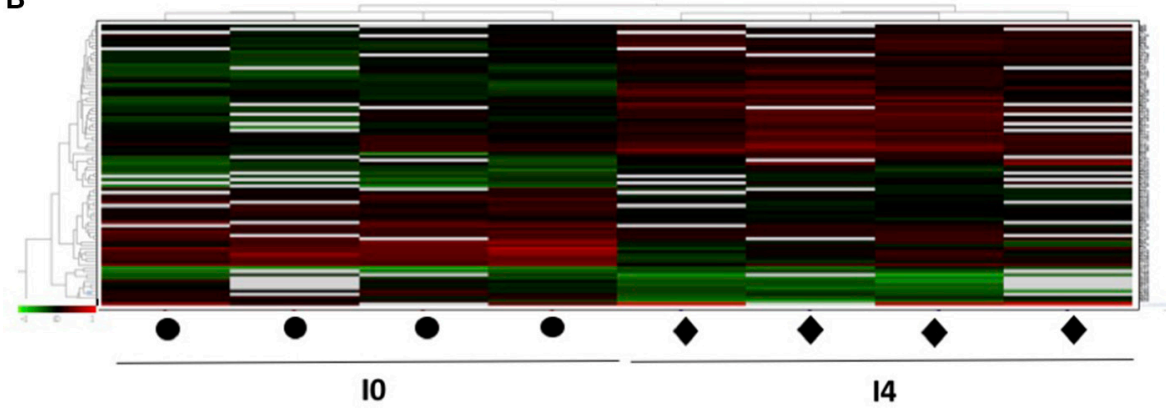

FIGURE 2 | (A) Principal Component Analyses (PCA) and (B) hierarchical cluster analyses of the protein spots (sub-sets) differentially expressed of paralarvae of Octopus vulgaris corresponding to the condition 1 (I4 vs. I0) considered as function of dietary group and age (details in Supplementary Table 3). \% of variance explained: $\mathrm{PC} 1=66.6 ; \mathrm{PC} 2=11.4$.

rapid growth undergone in this phase of the biological cycle, with amino acids as the main source of energy (Lopes et al., 2016) and glycolysis playing a secondary role in paralarvae development (Lee, 1994; Navarro et al., 2014). It is important to note, however, that in the early days posthatching paralarvae use yolk reserves. These include glycogen and triglycerides (Quintana et al., 2015). In both cases substrate is supplied for the GAPDH, either by glycolysis or by the incorporation of the glycerol from mono or triglycerides into the glycolytic pathway, as evidenced by the glycerol kinase (GyK) activity found in newly hatched paralarvae (Cardenete et al., 2016).

In condition 1 , unfed 4 days old paralarvae showed upregulation of S-crystallin 3 respect to hatchlings. This protein that is a structural constituent of the lenses of the eyes in octopus. $\mathrm{S}$-crystallins are soluble proteins in eye lens that contribute to the transparency and optical clarity (De Jong et al., 1989). The over-expression of this protein involved in vision, shows the importance of eyesight in paralarvae from the very beginning of their development, even under starving conditions. Although paralarvae are provided with chemoreceptors, they are mainly visual hunters (Lee, 1994; von Boletzky and Villanueva, 2014). Hatchlings enter in a planktonic phase, where they need to start feeding from the first day after hatching, and the active search (hunt) for food has been recorded 2 days after hatch at temperatures between 18 and $20^{\circ} \mathrm{C}$ (Iglesias et al., 2006), even before the yolk reserves are exhausted (Villanueva and Norman, 2008).

Regarding energetic metabolism, in condition 1 it can be observed how triosephosphate isomerase (TPI) is down regulated in 4 days starved paralarvae with respect to hatchlings. This enzyme catalyzes the reversible transformation of dihydroxyacetone phosphate (DHAP) to glyceraldehyde 3-phosphate (GAP) in the glycolysis pathway. DHAP is mainly provided from glucose or glycerol from triglycerides. Thus, this 
A

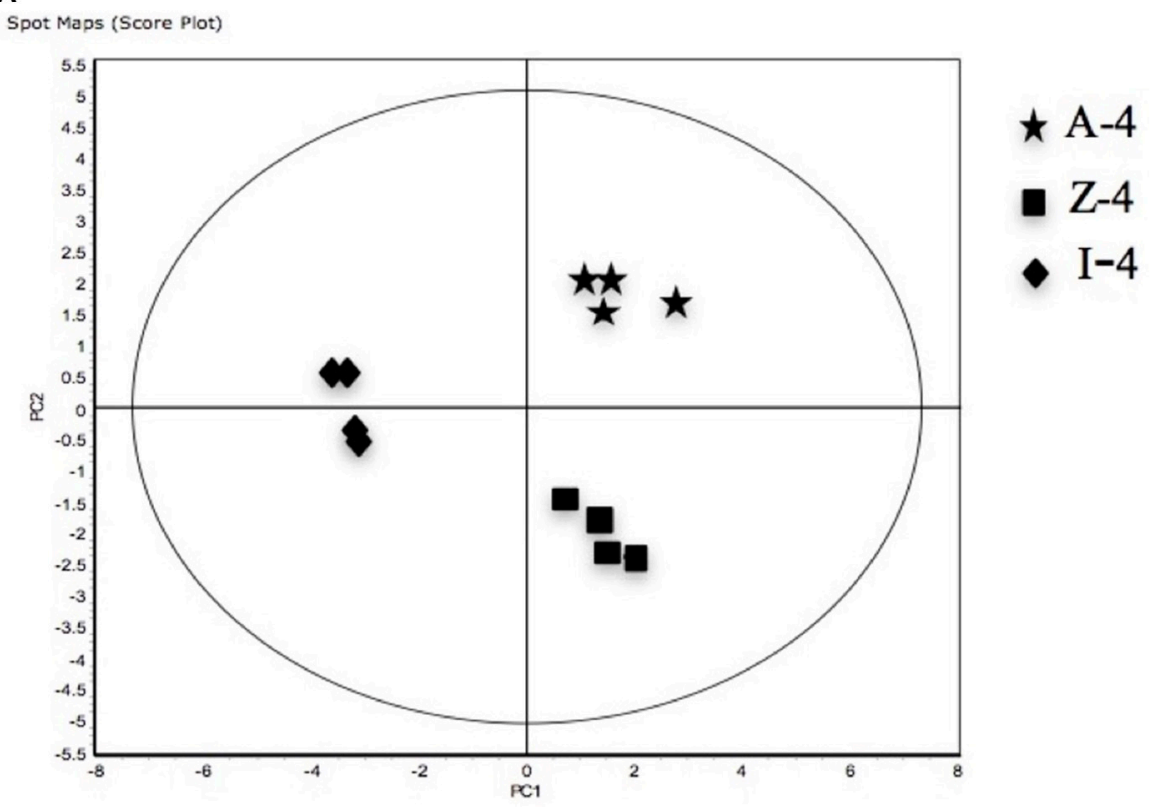

B

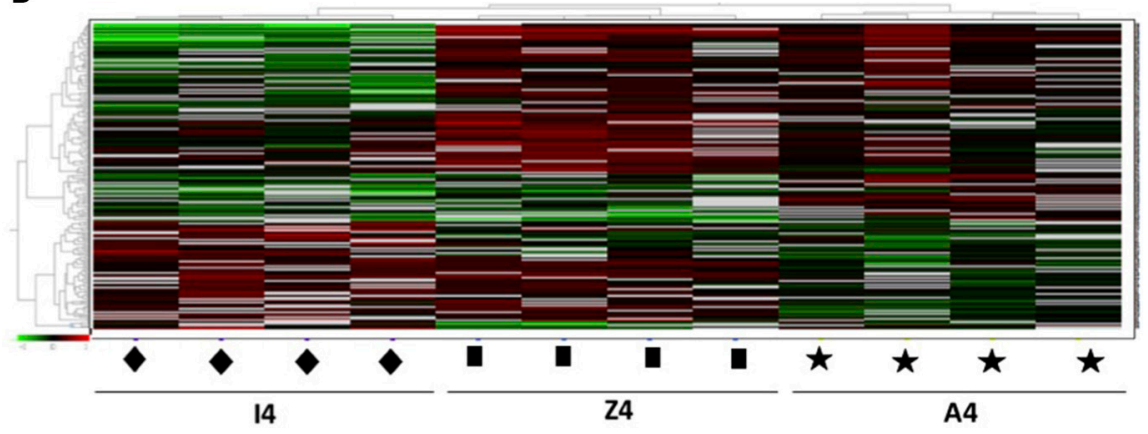

FIGURE 3 | (A) Principal Component Analyses (PCA) and (B) hierarchical cluster analyses of the protein spots (sub-sets) differentially expressed of paralarvae of Octopus vulgaris corresponding to the condition 2 (A4, Z4 vs. 14) considered as function of dietary group and age (details in Supplementary Table 3). \% of variance explained: PC1 $=73.7 ;$ PC2 $=9.6$.

fact points to a decrease in energy production by glycolysis and/or catabolism of triglycerides, which is in agreement with the fasting situation of paralarvae, and with the foreseeable exhaustion of the yolk reserves which, under normal conditions, are completely depleted around 4-5 days after hatching (Nande et al., 2017)

Usually the enzymatic reaction catalyzed by TPI runs to the formation of GAP, due that this one is rapidly eliminated by the following reaction of the glycolytic pathway that is catalyzed by the GAPDH enzyme (Blacklow et al., 1988; Harris et al., 1998). In this case, GADPH is lightly over regulated and therefore, there is a contrasting situation that should lead to a decrease of the GAP substrate. Obviously, in this case, the over expression of GADHP found, would be more related with the other functions of this enzyme mentioned above (i.e., $\mathrm{NADH}$ production) than with the obtention of energy by glycolysis.

Beta actin is also up-regulated in unfed 4 days old paralarvae which is part of the components of the cell cytoskeleton.
This protein is highly conserved and is involved in support and different types of cell motility. Cephalopods, especially at paralarvae stages, display high growth rates, and proteins of cytoskeleton may be of paramount importance during their development.

HSP70 was down-regulated in unfed octopus paralarvae. These results are in line with a previous study, where starvation was related with decreased HSP70 levels in 4 days old octopus paralarvae, whereas increased HSP70 levels were detected in fed paralarvae (Varó et al., 2013). Previous studies on early life stages, mainly in fish, indicate variability in HSP70 response related to starvation. In fact, increased (Cara et al., 2005), decreased (Deng et al., 2009), or unchanged (Han et al., 2012) HSP70 levels have been found in fish larvae related with starvation or during food restriction. HSP70 is a chaperone protein that assists in the folding and transport of other proteins, and thus can be critical in periods of rapid growth (Kiang and 


\section{A}

Spot Maps (Score Plot)

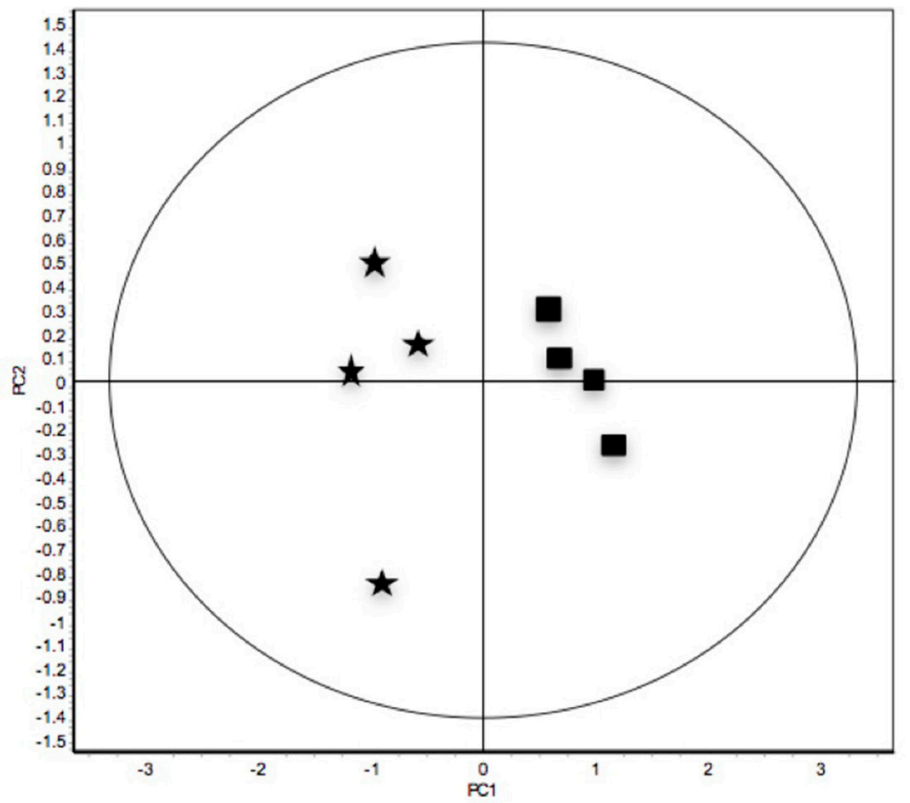

Z-4

$\star$ A-4

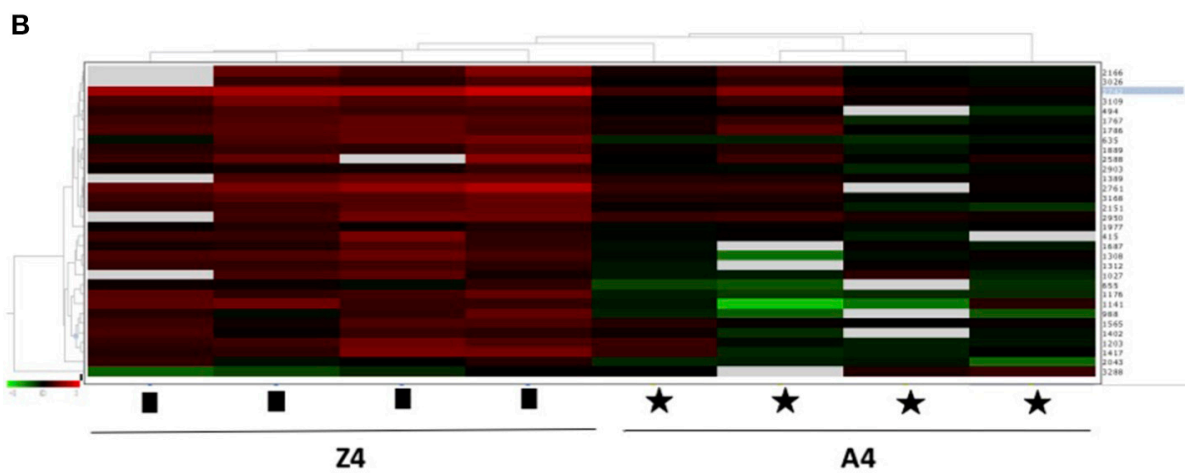

FIGURE 4 | (A) Principal Component Analyses (PCA) and (B) hierarchical cluster analyses of the protein spots (sub-sets) differentially expressed of paralarvae of Octopus vulgaris corresponding to the condition 3 (Z4 vs. A4) considered as function of dietary group and age (details in Supplementary Table 3). \% of variance explained: $\mathrm{PC} 1=77.1 ; \mathrm{PC} 2=8.3$.

Tsokos, 1998). Thus, its expression can be altered by several stressors, including nutritional stress, caused by starvation. High growth rates in cephalopods are based in increasing body mass by protein synthesis and accretion, especially at paralarvae stages, that require large amounts of proteins and amino acid in the diet to satisfy the energy demands (Navarro et al., 2014). In larval fish, starvation is associated to amino acid restriction and enhanced proteolysis that affect cellular protein homeostasis, which translates into lower growth and survival (Conceição et al., 1997). For example, in white sturgeon larvae (Acipenser transmontanus) starvation reduced the induction of HSPs (HSP70 and HSP90), and decreased the body weight (Han et al., 2012). The growth (dry weigh) of unfed paralarvae group was much lower $(0.177 \pm 0.070 \mathrm{mg})$, compared to hatchlings $(0.333 \pm 0.080 \mathrm{mg})$ and 4 days old fed paralarvae groups (Z: $0.411 \pm 0.014 \mathrm{mg} ; A$ : $0.367 \pm 0.033 \mathrm{mg}$ ), with a loss of their initial weigh around 50\% (47.7\%). In agreement with former larval fish observations, the down-regulation of HSP70 found in starved paralarvae could be related with lower metabolic rates, linked with restriction of protein and amino acid anabolism, resulting in a lower or poor growth.

GST also showed down-regulation in unfed paralarvae. This enzyme is implicated in the detoxification of reactive electrophilic compounds and xenobiotic substances as antioxidant defense. Although changes of antioxidant defense have been associated with aging in invertebrates, including cephalopods (Zielinski and Pörtner, 2000; Barata et al., 2005), the accumulation of defective macromolecules caused by age has been related with increase of oxidative damage and/or by loss of the ability to repair or degradate these molecules (Stadtman, 1992, in Zielinski and Pörtner, 2000). Our results suggest that the decrease in GST could lead to the accumulation of electrophilic molecules indicating 


\section{A}
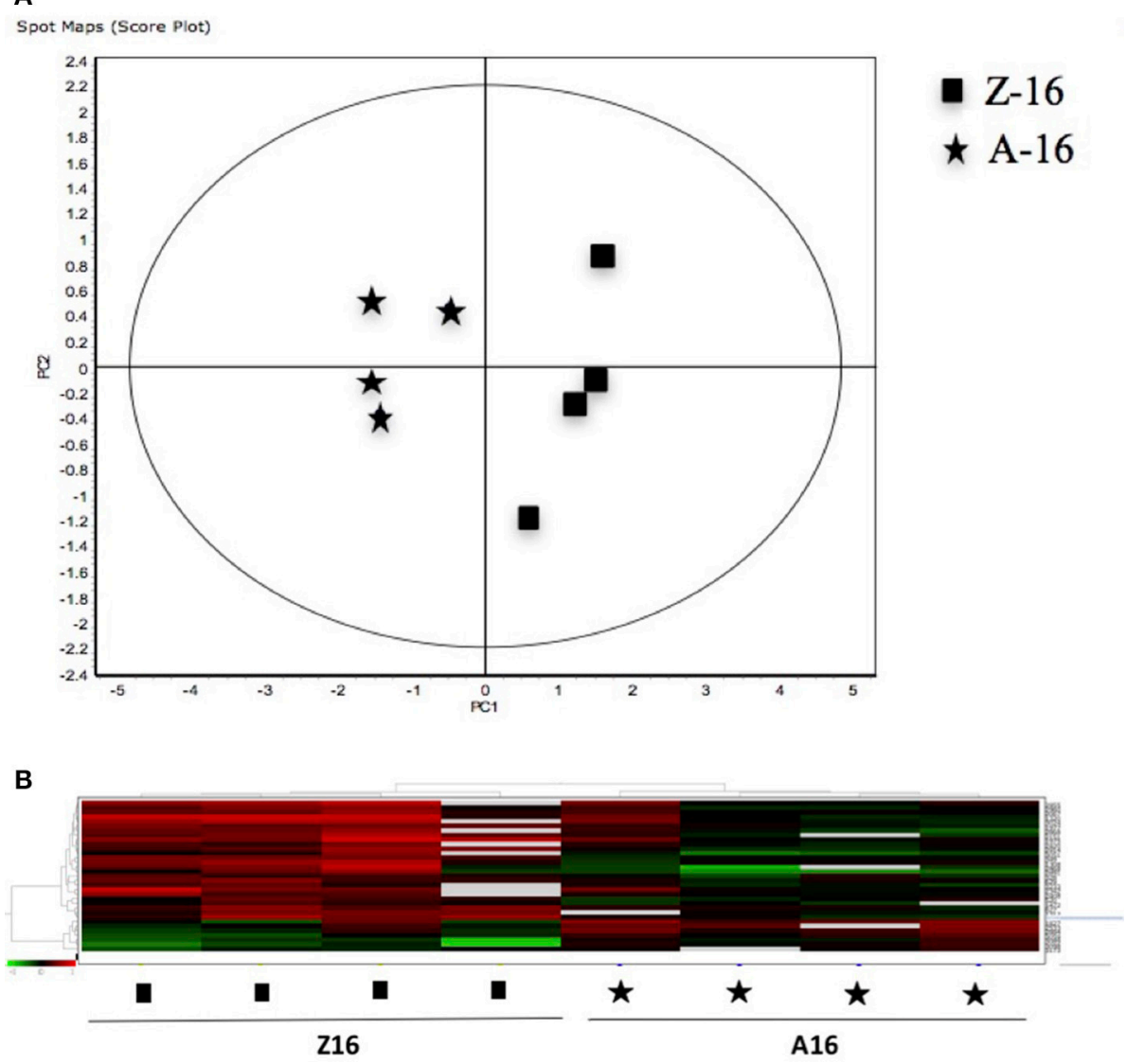

FIGURE 5 | (A) Principal Component Analyses (PCA) and (B) hierarchical cluster analyses of the protein spots (sub-sets) differentially expressed of paralarvae of Octopus vulgaris corresponding to the condition 4 (Z16 vs. A16) considered as function of dietary group and age (details in Supplementary Table 3). \% of variance explained: $\mathrm{PC} 1=72.6 ; \mathrm{PC} 2=8$.

TABLE 2 | Summary of the fold changes in expression of protein identities differentially expressed in 0 . vulgaris paralarvae in the different condition studied as function of dietary group and age.

\begin{tabular}{|c|c|c|c|c|}
\hline Protein name & $\begin{array}{l}\text { Condition } 1 \\
14 \text { vs. } 10\end{array}$ & $\begin{array}{c}\text { Condition } 2 \\
\text { A4, Z4 vs. } 14\end{array}$ & $\begin{array}{l}\text { Condition } 3 \\
\text { Z4 vs. A4 }\end{array}$ & $\begin{array}{l}\text { Condition } 4 \\
\text { Z16 vs. A16 }\end{array}$ \\
\hline S-crystallin 3 & $\uparrow(1.94)$ & $\uparrow(8.44)$ & & $\downarrow(-2.27)$ \\
\hline Beta actin & $\uparrow(1.35)$ & & & \\
\hline Heat shock protein $70 \mathrm{KDa}$ & $\downarrow(-2.08)$ & & & \\
\hline Nitrilase & & $\uparrow(4.25)$ & $\downarrow(-1.73)$ & $\downarrow(-2.56)$ \\
\hline $\mathrm{NADP}^{+}$specific isocitrate dehydrogenase & & $\uparrow(7.72)$ & & $\downarrow(-2.85)$ \\
\hline Actin & & $\uparrow(3.76)$ & & \\
\hline Actin beta/gamma1 & & $\uparrow(2.25)$ & $\uparrow(1.52)$ & \\
\hline Arginine kinase & & $\uparrow(19.5)$ & $\uparrow(2.66)$ & \\
\hline
\end{tabular}

$\uparrow$, up-regulated; $\downarrow$, down-regulated in each condition studied. (), fold change values. I, unfed group; A, Artemia group; Z, zoeae group. Number indicates age (days). vs., versus.

a detrimental effect on starved paralarvae. This, together with the decrease in HSP70, also involved in cellular defense, would constitute a response to an advanced stress scenario in unfed paralarvae. However, the lower metabolic rate probably produced by fasting could also reduce the levels of GST, as pointed out by Morales et al. (2011). In fish the transcriptional response of 
GST to starvation varies according to tissue, species and fasting length. Thus, while in cod muscle (G. morhua) GST does not show modifications, in liver GST increases after short periods of fast in rock bream (Oplegnatus faciatus), whereas in rainbow trout (Onconhynchus mykiss) GST decreases in fish starved for 3 or more weeks (Morales et al., 2011). Interestingly, GST is related with S-crystallin in cephalopods. In fact, as pointed out by Tomarev et al. (1991) the use of detoxification stress proteins like GST and aldehyde dehydrogenase as cephalopod crystallins, is indicative of a common strategy for recruitment of enzymecrystallins during the convergent evolution of vertebrate and invertebrate lenses. A recent study on $O$. vulgaris has revealed that the loss of GST enzyme activity in lens tissue is linked to the enhanced protein stability of S-crystallin via glutathione binding (Tan et al., 2016). In the light of these data, and although protein identification in our study was not carried out at the cellular location level, it is tempting to suggest that the decrease of GST might also be indicative of possible alterations in the lens structure of starved paralarvae.

In 4 days old fed paralarvae (condition 2), all proteins showing differential expression respect to unfed group were over expressed. It is interesting to highlight particularly the high overexpression of S-Crystalin 3 (8.44-fold change) that is in line with the former responses of this protein in 4 days old starving paralarvae, and support the crucial importance of eyes (vision). Particularly, S-Crystalin proteins, for their role in the refractive properties of the eye lens (Tomarev et al., 1991; Tomarev and Piatigorsky, 1996) may be of paramount importance in active visual hunters like octopuses for their adequate feeding and growth, especially during the first days of development, when adequate provision of essential nutrients is necessary for their rapid buildup. Thus, eye structure and function may be modulated by the feeding/nutritional (fed vs. starving) status of paralarvae and "vice versa."

Actin and actin beta/gamma1, cytoskeleton proteins, showed high increases in their expression in 4 days old fed groups respect to unfed ones, paralleling the high growth (dry weight, see above) and pointing at their importance in the development.

Nitrilase is also up-regulated in fed 4 days old paralarvae. This protein is part of a superfamily consisting in thiol enzymes involved in biosynthesis and post-translational modification of natural product in plants, animals, and fungi (Pace and Brenner, 2016). In this study, the sequence producing significant alignment of this protein (NCBI gi| 518224143) corresponds to a nitrilase described in Bacillus endophyticus. Bacterial nitrilases are used for biochemical synthesis and for environmental remediation (Cowan et al., 1998). A recent study has shown that B. endophyticus compared to different Bacillus strains has more genes related with energetic and transport metabolism of carbohydrates and lipids, than those related to cell envelope biogenesis and signal transduction mechanisms (Jia et al., 2015). This could suggest that the up-regulation of nitrilase could be linked to the bacterial metabolism that accompanies the gut microbiome of fed paralarvae, more than with the paralarval metabolism itself.

The high up regulation (7.72-fold change) of an isocitrate dehydrogenase isozyme dependent of $\mathrm{NADP}^{+}(\mathrm{NADP}-\mathrm{IDH})$, found in 4 days fed paralarvae (condition 2), point to a high activity of the Krebs cycle (TCA). In eukaryotes, there are three isozymes of IDH, two located in the mitochondrial matrix (NAD and NADP dependent respectively) related with energy production by TCA cycle and another one NADP dependent IDH in cytosol, which provides NADPH. The latter is necessary for the maintenance of the reduced glutathione and peroxiredoxin antioxidant systems by mean of the enzymes glutathione reductase (GR) and thioredoxin reductase (TrxR) respectively (Xu et al., 2004; Tomanek and Zuzow, 2010; Tomanek, 2015). Both systems are required to prevent the deleterious effect of reactive oxygen species (ROS). In condition 2, fed paralarvae seem to have a high aerobic metabolism and an up regulation in the production of NADPH. To account for this production, it is necessary to provide continuously substrate to the IDH catalyzed reaction. In short, sufficient citrate synthesis should be produced by a previous reaction of the Krebs cycle catalyzed by the enzyme citrate synthase. Therefore, a sustained supply of citrate synthase substrates: oxaloacetate and acetyl coenzyme A, are required (Tomanek and Zuzow, 2010). The results of Cardenete et al. (2016) seem to support this. In fact, 3 days old octopus paralarvae (fed Artemia) showed a significant increase in glutamate oxaloacetate transaminase activity (GOT, enzyme that produce oxaloacetate) as well as an increase in the activity of $\beta$ hydroxyacyl CoA dehydrogenase (HOAD), a key enzyme in beta oxidation of fatty acids, process that produces acetyl CoA. Both activities are also indicative of a high level of aerobic metabolism.

With regard to arginine kinase, the enzyme that shows the higher up regulation (19.5-fold), it catalyzes the first step of the arginine phosphate system that provides anaerobic fuel in several invertebrates including cephalopods (Fields et al., 1976; Gäde, 1980; Ellington, 2001). The system produces ATP in a first step breaking arginine phosphate, stored in mollusk muscles (Regnouf and van Thoai, 1970), by means of the activity of arginine kinase $(\mathrm{AK})$, producing arginine and ATP. In a second step the condensation of the amino acid arginine with pyruvate takes place. This reaction produces octopine and it is catalyzed by the NADH dependent enzyme octopine dehydrogenase (ODH; Fields et al., 1976). In this context, the over expression of GAPDH found may be explained, since it provides the NADH required by AK activity.

The function of this anaerobic way of obtaining energy is related in paralarvae with episodes of physiological hypoxia in muscle when there is a great demand of energy as it happens in fast and intensive swimming (Baldwin, 1982; Lee, 1994). Indeed, it is associated to prey capture by paralarvae, that involves bursts of swimming energetically very expensive (Baldwin, 1982). In agreement with these data, octopine dehydrogenase activity shows a significant increase in the first days of paralarvae life (Cardenete et al., 2016), indicating an increase in the predatory capacity of the paralarvae with their development.

In conditions 3 and 4 , when both dietary groups are compared (see Table 2), proteins with differential expression showed similar changes in their abundance, suggesting that they were most probably related to development (age) than to diet. The two diets supplied were more different in qualitative than in quantitative composition, with the co-feeding treatment 
providing essential lipids in comparison with the diet based solely in Artemia. In fact, every effort was made to adjust food so that there was equivalent prey density in both dietary treatments, hence the co-feeding schedule. All these suggestions, however must be contemplated with care since working with live preys is always difficult to handle and control. Suffice to say that octopus paralarvae are active selective predators as has been reported recently (Roura et al., 2012). It must be pointed out however, that until the nutritional requirements of the paralarvae are well established, helping to design and produce adequate inert diets, live food remains the best alternative. Experimental designs focused on unveiling differential expressions of proteins linked to specific aspects of food composition should be foreseen in future works to help to cope with these aspects, but were beyond the scope of the present work.

It is to note that in the zoeae fed group, S-crystallin 3 showed significant change only in 16 days old paralarvae (Z16, condition 4 ), decreasing by 2.27 -fold. In view of all the changes of this protein in the different condition studied (see Table 2), one would conclude that starvation seems to affect more to the eye lens structure in 16 days old paralarvae fed with zoeae than with Artemia. As mentioned above, alterations in the eye lens structure, lower transparency and optical clarity should produce altered vision and less success in hunting and feeding. This should translate in lower growth. Although Z16 paralarvae showed higher DW $(0.713 \pm 0.062 \mathrm{mg})$ and specific growth rate (SGR, \% DW day ${ }^{-1}: 4.961 \pm 0.58$ ) compared with Artemia fed group (DW: $0.621 \pm 0.051 \mathrm{mg}$; SGR: $4.043 \pm 0.55$ ), as previously discussed by Garrido et al. (2016a), no significant differences in growth were found between both dietary groups. Although it is always delicate to make direct comparisons due to differences in methodologies and feeding schemes (aggravated by the use of live preys), as well as variability in spawn quality (Garrido et al., 2017), it is to note that other trials using zoeae as food have reported higher growth (Iglesias et al., 2004, 2014; Carrasco et al., 2006; Iglesias and Fuentes, 2014). Thus, bearing in mind that adequate prey density at this stage of development is critical (Villanueva et al., 2002), the decrease in S-crystallin 3 in zoeae group could be a response of paralarvae to starvation, more than to the qualitative composition of the diet. This protein would act then as a biomarker of starvation pointing at this condition in the co-feeding treatment as it did in 4 days old starved paralarvae. In fact, co-feeding was used because there was not guarantee of enough provision of zoeae to fulfill the necessary prey density, and paralarvae are selective feeders.

The down-regulation of nitrilases found in the zoeae group at 4 and 16 days (condition 3 and 4) compared to the Artemia group suggest, in agreement with the former observations (condition 2) linking these proteins to bacterial nitrilases metabolism present in the gut microbiome of fed paralarvae, that this bacterial metabolism was lower in co-fed paralarvae, perhaps in line with a scarcity of food scenario.

The up-regulation of cytoskeleton proteins, actin and actin beta/gammal, together with the increase in arginine kinase, involved in energy production (ATP) found only in 4 days old paralarvae fed with zoeae, supports the importance of structural and energetic proteins in the enhanced growth of this group compared with Artemia in periods of high energy demand as occurs in the first 4 days of the octopus' development. On the other hand, the down regulation of $\mathrm{NADP}^{+}$specific isocitrate dehydrogenase suggests a shift toward anaerobic metabolism in 16 days old paralarvae fed with zoeae, as compared with the high up regulation found in 4 days old fed paralarvae.

Overall, the results show that in 4 days old zoeae fed paralarvae, all the proteins identified were up regulated, which could be associated with higher growth (DW) than in the case of those Artemia fed. On the contrary, at 16 days the proteins identified were down regulated in the zoeae group, except GAPDH that was always up regulated in all the conditions studied. The consistency of the up-regulation in the rest of the different feeding conditions suggests that the decrease in the zoeae group at 16 days might represent an indication of nutritional stress in paralarvae linked to insufficient availability of food.

\section{CONCLUSION}

In summary, the results obtained in the pattern of protein expression allow defining characteristic proteomes of paralarvae of $O$. vulgaris depending on diet and age. This study showed that proteome of $O$. vulgaris paralarvae is affected by fasting during the first 4 day of development, with proteins like S-crystallin, arginine kinase and $\mathrm{NAD}^{+}$specific isocitrate dehydrogenase showing the highest over expression in fed respect to unfed paralarvae. When both Artemia and Artemia plus zoeae dietary groups are compared, the up regulation of the proteins identified in 4 days old zoeae fed paralarvae, followed by the decrease found at 16 days old, might suggest an indication of nutritional stress in this group linked to starvation in a sub-optimal prey concentration scenario, more than with the quality of the diet. Although co-feeding is currently a good strategy to balance the quality of diet for achieving the best growth and survival in on growing octopus paralarvae during the first days of development, later around16 days of development, every effort has to be made to supply adequate amounts of food. Overall, the changes in the abundance of proteins like S-crystallin, arginine kinase and $\mathrm{NAD}^{+}$specific isocitrate dehydrogenase may be used as novel biomarkers to assess the nutritional status of octopus paralarvae. Their increase/decrease in abundance may be related to fed vs. starving paralarvae, particularly in the first 4 days of development. Proteomics techniques represent not only an invaluable approach to go beyond the "state of evidence" in the search for the causes of poor performance of paralarval cultures at present, but are also a promising tool for fine tuning welfare once the main problems and constraints are overcome.

\section{AUTHOR CONTRIBUTIONS}

IV: Design of proteomic procedures, analysis, and interpretation of the findings, and draft and writing of the manuscript. GC: Interpretation of the findings, writing discussion (metabolism) and revision of the manuscript. OM and FH: Analysis and interpretation of the findings, and general writing of the manuscript. JI and JO: Octopus paralarvae cultures and execution of the experiments. EA: Design experiments and 
revision of the manuscript. JN: Interpretation of the findings, writing and revision of the manuscript.

\section{FUNDING}

This study was funded by the "Ministerio de Economía y Competividad (Spanish Government)" under the projects OCTOPHYS (AGL-2010-22120-CO3-02) and OCTOWELF (AGL2013-49101-C2-2-R), and by the "Generalitat Valenciana" under the project PROMETEO II/2014/085.

\section{ACKNOWLEDGMENTS}

We acknowledge support of the publication fee by the CSIC Open Access Publication Support Initiative through its Unit

\section{REFERENCES}

Baldwin, J. (1982). Correlations between enzyme profiles in cephalopods muscle and swimming behavior. Pacific Sci. 36, 349-356.

Barata, C., Navarro, J. C., Varo, I., Riva, M. C., Arun, S., and Porte, C. (2005). Changes in antioxidant enzyme activities, fatty acid composition and lipid peroxidation in Daphnia magna during the aging process. Comp. Biochem. Physiol. B 140, 81-90. doi: 10.1016/j.cbpc.2004.09.025

Barber, R. D., Harmer, D. W., Coleman, R. A., and Clark, B. J. (2005). GAPDH as a housekeeping gene: analysis of GAPDH mRNA expression in a panel of 72 human tissues. Physiol. Genomics 21, 389-395. doi: 10.1152/physiolgenomics.00025.2005

Baumgarner, B. L., Bharadwaj, A. S., Inerowicz, D., Goodman, A. S., and Brown, P. B. (2013). Proteomic analysis of rainbow trout (Oncorhynchus mykiss) intestinal epithelia: physiological acclimation to short-term starvation. Comp. Biochem. Physiol. 8D, 58-64. doi: 10.1016/j.cbd.2012.11.001

Baumgarner, B. L., Riley, C. P., Sepulveda, M. S., Brown, P. B., Meyer, J. L., and Adamec, J. (2012). Increased expression of GAPDH protein is not indicative of nitrosative stress or apoptosis in liver of starved rainbow trout Oncorhynchus mykiss. Fish Physiol. Biochem. 38, 319-327. doi: 10.1007/s10695-011-9509-9

Blacklow, S. C., Raines, R. T., Lim, W. A., Zamore, P. D., and Knowles, J. R. (1988). Triosephosphate isomerase catalysis is diffusion controlled. Biochemistry 27, 1158-1167. doi: 10.1021/bi00404a013

Cara, J. B., Aluru, N., Moyano, F. J., and Vijayan, M. M. (2005). Fooddeprivation induces HSP70 and HSP90 protein expression in larval gilthead sea bream and rainbow trout. Comp. Biochem. Physiol. B 142, 426-431. doi: 10.1016/j.cbpb.2005.09.005

Carrasco, J. F., Arronte, J. C., and Rodríguez, C. (2006). Paralarval rearing of the common octopus, Octopus vulgaris (Cuvier). Aquacult. Res. 37, 1601-1605. doi: 10.1111/j.1365-2109.2006.01594.x

Cardenete, G., Morales, A. E., Hidalgo, M. C., Felipe, B., Lago, M. J., Gestal, C., et al. (2016). Time-course of metabolic profile of common octopus (Octopus vulgaris) paralarvae in the first stages of life. Abstr. Aquaculture Eur. 16, 175-176.

Conceição, L. E. C., Van Der Meeren, T., Verreth, J. A. J., Evjen, M. S., Houlihan, D. F., and Fyhn, H. J. (1997). Amino acid metabolism and protein turnover in larval turbot (Scophthalmus maximus) fed natural zooplankton or Artemia. Mar. Biol. 129, 255-265. doi: 10.1007/s002270050166

Cowan, D., Cramp, R., Pereira, R., Graham, D., and Almatawah, Q. (1998). Biochemistry and biotechnology of mesophilic and thermophilic nitrile metabolizing enzymes. Extremophiles 2, 207-216. doi: 10.1007/s007920050062

De Jong, W. W., Hendriks, W., Mulders, J. W. M., and Bloemendal, H. (1989). Evolution of eye lens crystallins: the stress connection. Trends Biochem. Sci. 14, 365-360. doi: 10.1016/0968-0004(89)90009-1

Deng, D. F., Wang, C., Lee, S., Bai, S., and Hung, S. S. O. (2009). Feeding rates affect heat shock protein levels in liver of larval white of Information Resources for Research (URICI). Proteomics study was done at Proteomics laboratory of University of Valencia (SCSIE). This laboratory is a member of Proteored, PRB2-ISCIII and is supported by grant PT13/0001, of the PE I + D $+\mathrm{i}$ 2013-2016, funded by ISCIII and FEDER. The authors acknowledge COST for funding the Action FA1301 "A network for improvement of cephalopod welfare and husbandry in research, aquaculture and fisheries (CephsInAction)," supporting this work.

\section{SUPPLEMENTARY MATERIAL}

The Supplementary Material for this article can be found online at: http://journal.frontiersin.org/article/10.3389/fphys. 2017.00309/full\#supplementary-material

sturgeon (Acipenser transmontanus). Aquaculture 287, 223-226. doi: 10.1016/j.aquaculture.2008.10.041

Ellington, W. R. (2001). Evolution and physiological roles of phosphagen systems. Annu. Rev. Physiol. 63, 289-325. doi: 10.1146/annurev.physiol.63.1.289

Fields, J. H. A., Baldwin, J., and Hochachka, P. W. (1976). On the role of octopine dehydrogenase in cephalopod mantle muscle metabolism. Can. J. Zool. 54, 871-878. doi: 10.1139/z76-099

Fiorito, G., Affuso, A., Basil, J., Cole, A., De Girolamo, P., D’angelo, L., et al. (2015). Guidelines for the care and welfare of cephalopods in research. A consensus based on an initiative by CephRes, FELASA and the Boyd Group United States of America. Lab. Anim. 49, 1-90. doi: 10.1177/0023677215580006

Fuentes, L., Sánchez, F. J., Lago, M. J., Iglesias, J., Pazos, G., and Linares, F. (2011). Growth and survival of Octopus vulgaris (Cuvier 1797) paralarvae fed on three Artemia-based diets complemented with frozen fish flakes, crushed zooplankton and marine microalgae. Sci. Mar. 75, 771-777. doi: 10.3989/scimar.2011.75n4771

Gäde, G. (1980). A comparative study of octopine dehydrogenase isoenzymes in gastropod, bivalve and cephalopod mollusks. Comp. Biochem. Physiol. 67, 575-558.

Garrido, D., Martín, V. M., Rodríguez, C., Iglesias, J., Navarro, J. C., Estévez, A., et al. (2016a). Meta-analysis approach to the effects of live prey on the growth of Octopus vulgaris paralarvae under culture conditions. Rev. Aquacult. 1-12. doi: $10.1111 /$ raq. 12142

Garrido, D., Navarro, J. C., Perales-Raya, C., Nande, M., Martín, M. V., Iglesias, J., et al. (2016b). Fatty acid composition and age estimation of wild Octopus vulgaris paralarvae. Aquaculture 464, 564-569. doi: 10.1016/j.aquaculture. 2016.07.034

Garrido, D., Varó, I., Morales, A. E., Hidalgo, M. C., Navarro, J. C., Hontoria, F., et al. (2017). Assessment of stress and nutritional biomarkers in cultured Octopus vulgaris paralarvae: effects of geographical origin and dietary regime. Aquaculture 468, 558-568. doi: 10.1016/j.aquaculture.2016.11.023

Gong, Y., Cui, L., and Minuk, G. Y. (1996). Comparison of glyceraldehyde-3phosphate dehydrogenase and 28S-ribosomalRNA gene expression in human hepatocellular carcinoma. Hepatology 23, 734-737. doi: 10.1002/hep.5102 30413

Han, D., Huang, S. S. Y., Wang, W. F., Deng, D. F., and Hung, S. S. O. (2012). Starvation reduces the heat shock protein responses in white sturgeon larvae. Environ. Biol. Fishes 93, 333-342. doi: 10.1007/s10641-011-9918-8

Harris, T. K., Cole, R. N., and Mildvan, A. (1998). Proton transfer in the mechanism of triosephosphate isomerase. Biochemistry 37, 16828-16838. doi: 10.1021/bi982089f

Iglesias, J., and Fuentes, L. (2014). “Octopus vulgaris. paralarval culture," in Cephalopod Culture, eds J. Iglesias, L. Fuentes, and R. Villanueva (Dordrecht: Springer Netherlands), 427-450.

Iglesias, J., Fuentes, L., Sánchez, J., Otero, J. J., Móxica, C., and Lago, M. J. (2006). First feeding of Octopus vulgaris Cuvier, 1797 paralarvae using Artemia: effect 
of prey size, prey density and feeding frequency. Aquaculture 261, 817-822. doi: 10.1016/j.aquaculture.2006.08.002

Iglesias, J., Otero, J. J., Móxica, C., Fuentes, L., and Sánchez, F. J. (2004). The completed life cycle of the Octopus (Octopus vulgaris, Cuvier) under culture conditions: paralarval rearing using Artemia and zoeae, and first data on juvenile growth up to 8 months of age. Aquacult. Int. 12, 481-487. doi: 10.1023/B:AQUI.0000042142.88449.bc

Iglesias, J., Pazos, G., Fernández, J., Sánchez, F. J., Otero, J. J., Domingues, P., et al. (2014). The effects of using crab zoeae (Maja brachydactyla) on growth and biochemical composition of Octopus vulgaris (Cuvier 1797) paralarvae. Aquacult. Int. 22, 1041-1051. doi: 10.1007/s10499-013-9725-7

Iglesias, J., Sanchez, F. J., Bersano, J. G. F., Carrasco, J. F., Dhont, J., Fuentes, L., et al. (2007). Rearing of Octopus vulgaris paralarvae: present status, bottlenecks and trends. Aquaculture 266, 1-15. doi: 10.1016/j.aquaculture.2007.02.019

Jayasundara, N., Tomanek, L., Dowd, W. W., and Somero, G. N. (2015). Proteomic analysis of cardiac response to thermal acclimation in the eurythermal goby fish Gillichthys mirabilis. J. Exp. Biol. 218, 1359-1372. doi: 10.1242/jeb.118760

Jia, N., Du, J., Ding, M. Z., Gao, F., and Yuan, Y. J. (2015). Genome sequence of Bacillus endophyticus and analysis of its companion mechanism in the Ketogulonigenium vulgare-Bacillus strain consortium. PLoS ONE 10:e0135104. doi: 10.1371/journal.pone. 0135104

Jury, D. R., Kaveti, S., Duan, Z.-H., Willard, B., Kinter, M., and Londraville, R. J. (2008). Effects of calorie restriction on the zebrafish liver proteome. Comp. Biochem. Physiol. D 3, 275-282. doi: 10.1016/j.cbd.2008.07.003

Kiang, J. G., and Tsokos, G. C. (1998). Heat shock protein 70 kDa: molecular biology, biochemistry, and physiology. Pharmacol. Ther. 80, 183-201. doi: 10.1016/S0163-7258(98)00028-X

Lee, P. G. (1994). Nutrition of cephalopods: fueling the system. Mar. Fresh. Behav. Physiol. 25, 25-35.

Lopes, V. M., Faleiro, F., Baptista, M., Pimentel, M. S., Paula, J. R., Couto, et al. (2016). Amino and fatty acid dynamics of octopus (Octopus vulgaris) early life stages under ocean warming. J. Therm. Biol. 55, 30-38. doi: 10.1016/j.jtherbio.2015.11.006

Mansur, N. R., Meyer-Siegler, K., Wurzer, J. C., and Sirover, M. A. (1993). Cell cycle regulation of the glyceraldehyde-3-phosphate/uracil DNA glycosylase gene in normal human cells. Nucleic Acids Res. 21, 993-998. doi: 10.1093/nar/21.4.993

Martin, S. A., Vilhelmsson, O., Médale, F., Watt, P., Kaushik, S., and Houlihan, D. F. (2003). Proteomic sensitivity to dietary manipulations in rainbow trout. Biochim. Biophys. Acta 1651, 17-29. doi: 10.1016/S1570-9639(03) 00231-0

Meyer-Siegler, K., Mansur, N. R., Wurzer, J. C., and Sirover, M. (1992). Proliferation-dependent regulation of the glyceraldehyde-3-phosphate dehydrogenase/uracil DNA glycosylase gene in human cells. Carcinogenesis 13, 2127-2132. doi: 10.1093/carcin/13.11.2127

Monroig, Ó., Guinot, D., Hontoria, F., Tocher, D. R., and Navarro, J. C. (2012a). Biosynthesis of essential fatty acids in Octopus vulgaris (Cuvier, 1797): molecular cloning, functional characterisation and tissue distribution of a fatty acyl elongase. Aquaculture 360-361, 45-53. doi: 10.1016/j.aquaculture.2012.07.016

Monroig, Ó., Navarro, J. C., Dick, J. R., Alemany, F., and Tocher, D. R. (2012b). Identification of a $\Delta 5$-like fatty acyl desaturase from the cephalopod Octopus vulgaris (Cuvier 1797) involved in the biosynthesis of essential fatty acids. Mar. Biotechnol. 14, 411-422. doi: 10.1007/s10126-011-9423-2

Morales, A. E., Pérez-Jiménez, A., Furné, M., and Guderley, H. (2011). "Starvation, energetics, and antioxidant defenses," in Oxidative Stress in Aquatic Ecosystems, eds T. Abele, D. Vázques-Medina, and J. P. Zenteno-Savin (Oxford: WileyBlacwell Publishing Ltd.), 281-294.

Móxica, C., Linares, F. Otero, J. J., Iglesias J., and Sánchez, F. J. (2002). Cultivo intensivo de paralarvas de pulpo, Octopus vulgaris Cuvier, 1797, en tanques de $9 \mathrm{~m} 3$. Bol. Inst. Esp. Ocean. 18, 31-36.

Nande, M., Iglesias, J., Domingues, P., and Pérez, M. (2017). Effect of temperature on energetic demands during the last stages of embryonic development and early life of Octopus vulgaris (Cuvier, 1797) paralarvae. Aquaculture Res. 48, 1951-1961. doi: 10.1111/are.13032

Navarro, J. C., Monroig, Ó., and Sykes, A. V. (2014). "Nutrition as a key factor for cephalopod aquaculture," in Cephalopod Culture, eds J. Iglesias, L. Fuentes, and R. Villanueva (Dordrecht: Springer Netherlands), 77-95.
Navarro, J. C., and Villanueva, R. (2000). Lipid and fatty acid composition of early stages of cephalopods: an approach to their lipid requirements. Aquaculture 183, 161-177. doi: 10.1016/S0044-8486(99)00290-2

Navarro, J. C., and Villanueva, R. (2003). The fatty acid composition of Octopus vulgaris paralarvae reared with live and inert food: deviation from their natural fatty acid profile. Aquaculture 219, 613-631. doi: 10.1016/S0044-8486(02)00311-3

Pace, H. C., and Brenner, C. (2016). The nitrilase superfamily: classification, structure and function. Genome Biol. 2, 1-9. doi: 10.1186/gb-2001-2-1-reviews0001

Quintana, D., Márquez, L., Arévalo, J. R., Lorenzo, A., and Almansa, E. (2015). Relationships between spawn quality and biochemical composition of eggs and hatchlings of Octopus vulgaris under different parental diets. Aquaculture 446, 206-216. doi: 10.1016/j.aquaculture.2015.04.023

Regnouf, F., and van Thoai, N. (1970). Octopine and lactate dehydrogenases in mollusk muscles. Comp. Biochem. Physiol. 32, 411-416. doi: 10.1016/0010-406X (70)90458-5

Rodríguez, C., and Carrasco, F. J. (1999). Engorde de pulpo (Octopus vulgaris Cuvier). Resultados de Crecimiento, Supervivencia y Reproducción. Abstract Retrieved from VII Congreso Nacional De Acuicultura. España: Las Palmas de Gran Canaria. 65.

Roos, B., and McArdle, H. J. (2008). Proteomics as a tool for the modelling of biological processes and biomarker development in nutrition research. $\mathrm{Br}$. J. Nutr. 99, s66-s71. doi: 10.1017/S0007114508006909

Roura, Á., González, Á. F., Redd, K., and Guerra, Á. (2012). Molecular prey identification in wild Octopus vulgaris paralarvae. Mar. Biol. 159, 1335-1345. doi: 10.1007/s00227-012-1914-9

Seixas, P., Otero, A., Valente, L. P., Dias, J., and Rey-Méndez, M. (2010). Growth and fatty acid composition of Octopus vulgaris paralarvae fed with enriched Artemia or co-fed with an inert diet. Aquacult. Int. 18, 1121-1135. doi: 10.1007/s10499-010-9328-5

Shevchenko, A., Jensen, O. N., Podtelejnikov, A. V., Sagliocco, F., Wilm, M., Vorm, O., et al. (1996). Linking genome and proteome by mass spectrometry: largescale identification of yeast proteins from two-dimensional gels. Proc. Natl. Acad. Sci. U.S.A. 93, 14440-14445. doi: 10.1073/pnas.93.25.14440

Sirover, M. A. (1997). Role of the glycolytic protein, glyceraldehyde-3phosphate dehydrogenase, in normal cell function and in cell pathology. J. Cell. Biochem. 66, 133-140. doi: 10.1002/(SICI)1097-4644(19970801) 66:2<133::AID-JCB1 $>3.0 . \mathrm{CO} ; 2-\mathrm{R}$

Sirover, M. A. (1999). New insight into an old protein: the functional diversity of mammalian glyceraldehyde-3-phosphate dehydrogenase. J. Biochim. Biophys Acta. 1432, 159-184.

Sirover, M. A. (2011). On the functional diversity of glyceraldehyde-3-phosphate dehydrogenase: biochemical mechanisms and regulatory control. Biochem. Biophys. Acta 1810, 741-751. doi: 10.1016/j.bbagen.2011.05.010

Smith, R. W., Cash, P., Ellefsen, S., and Nilsson, G. E. (2009). Proteomic changes in the crucian carp brain during exposure to anoxia. Proteomics 9, 2217-2229. doi: $10.1002 /$ pmic.200800662

Stadtman, E. R. (1992). Protein oxidation and aging. Science 257, 1220-1224. doi: $10.1126 /$ science. 1355616

Sveinsdóttir, H., and Gudmundsdóttir, Á. (2010). Proteome profile comparison of two differently fed groups of Atlantic cod (Gadus morhua) larvae. Aquacult. Nutr. 16, 662-670. doi: 10.1111/j.1365-2095.2010.00758.x

Tan, W. H., Cheng, S. C., Liu, Y. T., Wu, C. G., Lin, M. H., Chen, C. C., et al. (2016). Structure of a highly active cephalopod S-crystallin mutant: new molecular evidence for evolution from an active enzyme into lens-refractive protein. Sci. Rep. 6:31176. doi: 10.1038/srep31176

Tomanek, L. (2015). Proteomic responses to environmentally induced oxidative stress. J. Exp. Biol. 218, 1867-1879. doi: 10.1242/jeb.116475

Tomanek, L., and Zuzow, M. J. (2010). The proteomic response of the mussel congeners Mytilus galloprovincialis and $M$. trossulus to acute heat stress: implications for thermal tolerance limits and metabolic costs of thermal stress. J. Exp. Biol. 213, 3559-3574. doi: 10.1242/jeb. 041228

Tomarev, S. I., and Piatigorsky, J. (1996). Lens crystallins of invertebrates. Diversity and recruitment from detoxification enzymes and novel proteins. Eur. J. Biochem. 235, 449-465. doi: 10.1111/j.1432-1033.1996.00449.x 
Tomarev, S. I., Zinovieva, R. D., and Piatigorsky, J. (1991). Crystallins of the octopus lens. Recruitment from detoxification enzymes. J. Biol. Chem. 266, 24226-24231.

Tom Dieck, H., Döring, F., Fuchs, D., Roth, H. P., and Daniel, H. (2005). Transcriptome and proteome analysis identifies the pathways that increase hepatic lipid accumulation in zinc-deficient rats. J. Nutr. 135, 199-205.

Tristan, C., Shahani, N., Sedlak, T. W., and Sawa, A. (2011). The diverse functions of GAPDH: views from different subcellular compartments. Cell. Signal. 23, 317-323. doi: 10.1016/j.cellsig.2010.08.003

Varó, I., Navarro, J. C., Iglesias, J., Otero, J. J., Sánchez, J., Almansa, E., et al. (2013). Studies on the characterisation of biomarkers of nutritionally-derived stress in paralarval cultures of the common octopus (Octopus vulgaris). Commun. Agric. Appl. Biol. Sci. 78, 473-476.

Varó, I., Rigos, G., Navarro, J. C., del Ramo, J., Calduch-Giner, J., Hernandez, A., et al. (2010). Effect of ivermectin on the liver of gilthead sea bream Sparus aurata: a proteomic approach. Chemosphere 80, 570-577. doi: 10.1016/j.chemosphere.2010.04.030

Vaz-Pires, P., Seixas, P., and Barbosa, A. (2004). Aquaculture potential of the common octopus (Octopus vulgaris Cuvier, 1797): a review. Aquaculture 238, 221-238. doi: 10.1016/j.aquaculture.2004.05.018

Villanueva, R., and Norman, M. D. (2008). Biology of the planktonic stages of benthic octopuses. Ocean. Mar. Biol. Ann. Rev. 46, 105-202. doi: 10.1201/9781420065756.ch4

Villanueva, R., Riba, J., Koueta, N., and Boucaud-Camou, E. (2002). Growth and proteolytic activity of Octopus vulgaris paralarvae with different food rations during first feeding, using Artemia nauplii and compound diets. Aquaculture 205, 269-286. doi: 10.1016/S0044-8486(01)00678-0

von Boletzky, S., and Villanueva, R. (2014). "Cephalopod biology," in Cephalopod Culture, eds J. Iglesias, L. Fuentes, and R. Villanueva (Dordrecht: Springer Netherlands), 479-489.

Xu, X., Zhao, J., Xu, Z., Peng, B., Huang, Q., Arnold, E., et al. (2004). Structures of human cytosolic NADP-dependent isocitrate dehydrogenase reveal a novel self-regulatory mechanism of activity. J. Biol. Chem. 279, 33946-33957. doi: 10.1074/jbc.M404298200

Zielinski, S., and Pörtner, H. O. (2000). Oxidative stress and antioxidative defense in cephalopods: a function of metabolic rate or age? Comp. Biochem. Physiol. B 125, 147-160. doi: 10.1016/S0305-0491(99) 00162-5

Conflict of Interest Statement: The authors declare that the research was conducted in the absence of any commercial or financial relationships that could be construed as a potential conflict of interest.

Copyright (C) 2017 Varó, Cardenete, Hontoria, Monroig, Iglesias, Otero, Almansa and Navarro. This is an open-access article distributed under the terms of the Creative Commons Attribution License (CC BY). The use, distribution or reproduction in other forums is permitted, provided the original author(s) or licensor are credited and that the original publication in this journal is cited, in accordance with accepted academic practice. No use, distribution or reproduction is permitted which does not comply with these terms. 